\title{
Uncovering Political Ideology in the Translation of News Headlines in Relation to Palestinian-Israeli Conflict
}

\author{
Dr. Mohammed El Haj Ahmed* \\ Assistant Professor of Translation, Head of the English Department, Islamic University of Gaza \\ *Corresponding Author: Dr. Mohammed El Haj Ahmed, Assistant Professor of Translation, Head of the \\ English Department, Islamic University of Gaza
}

\begin{abstract}
The study aims at investigating the political ideology which interferes in the translation process of sensitive news headlines. The researcher selected news headlines from famous and various Israeli newspapers such as Haaretz, the Jerusalem post, Reuterz, and ArutzSheva about the events that followed Trump's recognition of Jerusalem as Israel's capital. The news headlines were given as a translation test to four Palestinian journalists. The results of the study show that the majority of the journalists resorted to dynamic renderings of the ST due to the high political sensitivity of the context that marks the news headlines. Faithfulness became irrelevant and the reality and truth of the ST were questioned and often subverted in the translation. The paper describes the nature and degree of translator interventions and outlines the strategies used to neutralize the ideological load invested in the original text.
\end{abstract}

Keywords: Ideology, News Headlines, Palestinian-Israeli Conflict, Strategies Translation

\section{INTRODUCTION}

The Palestinian-Israeli conflict is one of the longest and unsolved international problems in the world. The language used to represent this conflict in the media is frequently commented upon by various scholars and researchers. Translating such sensitive political news, such as this conflict, is not merely a rewriting from one language to another or reproducing another copy of the source language, but it goes beyond it to the extent that it may change the whole picture for the favor of a certain party over the other. Several studies were conducted to identify the factors that influence translators' decisions. One of the most influential factors is ideology. The translators' ideologies usually interfere in the messages impinged within the text intended for the target audience, whether the ideology itself was explicit, clearly noticed reactions and opinions, or implicit, manipulation with the linguistic choices. The translator becomes more visible when the text is of a highly sensitive nature. The social, political, and cultural environment that surrounds the translator can be manifested through his linguistic choices and acts of addition, omission, substitution can be applied by the translator.

For this study the researcher selected 15 news headlines that contain controversial items and discussed how they were translated by journalists.

\subsection{Need for the Study}

Many translators especially the ones lacking experience are not aware of some of the ideologically motivated meanings of the source text words. So this research paper provides translators, especially novice, ones with some guidelines for regarding highly sensitive texts in terms of strategies and techniques.

\subsection{Statement of the Problem}

This study is conducted to show to what extent the political ideology of the translators interferes in the translation of highly sensitive texts.

The problem of the study can be stated in the following main question:

To what extent does the political ideology of the translator interferes in the translation of sensitive news headlines related to the Palestinian-Israeli conflict?

The research sub-question is: 
What are the strategies used by journalists in translating sensitive news headlines?

\subsection{Purpose of the Study}

The main purpose of the study is to investigate the degree of the translators' interventions and mediations in the translation and outline the strategies used to neutralize the ideological load invested in the original text.

\subsection{Significance of the Study}

It is of great importance for translators to take into consideration the findings of this paper before translating any sensitive political texts, that are ideologically loaded, in which some strategies like literal translation does not work, whereas others such as functional translation may be the most suitable option.

\section{LiTERATURE REVIEW}

Ideology refers to the perceptions or propositions or assumptions we hold about ourselves, about others and about the world (Abdalla, 1994). As language is the only means through which human social relations are viewed, ideology is said to be inseparable from the linguistic code. Gee (1990) states that ideology plays a significant role in shaping discourse, while language users are sometimes active subjects in structuring discourse.

Much research from an ideological perspective is interested in uncovering manipulations in the TT that may be indicative of the translator's conscious ideology or produced by ideological elements of the translation environment, such as pressure from a commissioner, editor, or governmental circles. This is particularly the case in the translation of and adaptation of news translation that holds political ideology. (Munday, 2016).

Martin (2015) argues that political ideology has been a controversial topic for social analysts, and those who attempted to eschew judgmental reductions of others' conceptions and develop a nonpolemical political psychology found ideology behaving in ways that defeated their theories of political reasoning. He also argues that political ideology can best be understood as actors' theorization of their own position, and available strategies, in a political field.

Bhabha (1994) sees colonial power discourse as complicated and often camouflaged. However, its authority may be subverted by the production of a conflicted cultural hybridity that allows the discourse of the colonized to interrelate with it and then undermine it. The results are crucial for the translator. As Michaela Wolf (2000) states, 'the translator is no longer a mediator between two different poles, but her/his activities are inscribed in cultural overlappings which imply difference'.

Lefevere (1992) looks at translation as a rewriting of the original text. He focused on four factors that govern the reception 'acceptance or refusal' of the translation; that is, issues such as power, ideology, manipulation, and institution. He sees people in power positions are the responsible ones for rewriting literature and governing its consumption by the public and that the motivation behind such rewriting can be ideological 'with or against the dominant ideology' or poetological 'with or against the dominant poetics'.

Nida and Taber (1969) recommend using the dynamic equivalence when translating cultural specific items, where the relationship between receptor and message should be the same as that which existed between the original receptors and message. The message should be tailored to fit with the receptor's linguistic needs and cultural expectations and aims at complete naturalness of expression. Thus, dynamic equivalence achieves "the closest natural equivalent to the SL message in terms of meaning and style".

Van Dijk (1985) elaborated the significant role of ideology in translation. He distinguishes between explicit ideology, which refers to "explicitly verbalized opinions and attitudes", and implicit ideology, which includes the assumptions underlying the writer's linguistic choices. According to Van Dijk, the writer's lexical and syntactic choices are to reflect belief systems and to view the world from a particular stance. In the process of translation, ideologically linguistic structures of a source text could be manipulated intentionally because of inadequate language or translation skills, the requirements of the translation commission or the translator's own attitudes towards the source text topic. 
Farghal (1993) differentiates between two types of managing in translation, intrinsic and extrinsic. He defines the first as the inherent variations between the source text and the target text, and the second as the translator's practice of intervention in the original text to adjust the message to fit with his/her goals.

Fairclough (1995) gives comments on the strategies used by media institutions when reproducing dominant ideologies. There is a blurred boundary between primary discourse which is the voice of the writer of newspaper and secondary discourse which refers to organizations or individuals whose speech is quoted. This paves the way for press to change or manipulate what has been said to fit with their own ideology.

Finally, the researcher finds that most literature on ideology and its relation to translation shows how difficult and challenging to be a translator between different discourse worlds, cultures, values, and ideologies is. So journalists or news translators have to be inherently selective in the choices they make. They select, add, omit, adapt, adjust, and manipulate the original texts to meet the needs of the target text readers. For faithfulness to the source text, it becomes less important as long as the translator succeeded in conveying the message to the target audience.

This paper examines the degree of mediation manifested in the translation of Israeli news headlines by Palestinian journalists.

\section{Methodology}

The researcher selected news headlines from various Israeli newspapers such as Haaretz, the Jerusalem post, Reuterz, and ArutzSheva that addressed the incidents that occurred after Trump's recognition of Jerusalem as the capital of Israel. These newspapers are the most popular and accessible ones. The news headlines were given as a translation test to four Palestinian journalists from the Ministry of Information and Althorayya for Communication and Media. The translators are working for more than five years in these institutions where they translate and publish their work locally, regionally or internationally.

The translators were asked to translate the news headlines into Arabic with the assumption that the translation would appear in the Palestinian newspapers and websites they work with.

The analysis of the translations identifies the translators' degree of mediation and visibility, since the news headlines are of a sensitive nature, through the strategies they use.

\section{ANAlysis OF SOURCE AND TARget TeXT}

Gee (1990) states that ideology plays a significant role in shaping discourse. Yet, language users are sometimes active subjects in structuring discourse. According to Hatim and Mason (1990), translating is not a faithful product or neutral activity which means a translator does not only produce another copy of the original; otherwise the translation would become a mere reproduction of the ideology manifested in the ST. It would indeed diminish the adequacy of the TT if the motivation behind expressive lexical items is left unheeded. In this analysis, we want to discover to what extent the translator mediates or intervenes in the translation process to feed his own knowledge and beliefs.

In rendering the task, most translators used dynamic or functional equivalence, particularly in translating sensitive ideological items. They replaced the source text terms with target language expressions that meet the expectations of their Arabic audience, as seen in the following examples.

\subsection{Suicide Bombers Endanger Israeli Lives}

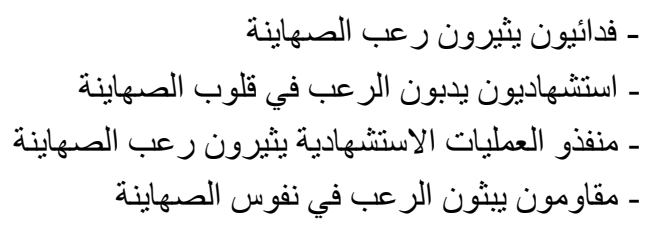

In the ST, the Israeli reporter used such expressive lexical choices as 'suicide bomber' to serve his attitudes and those of his Israeli or pro-Israeli readership. This lexis is highly charged since it contains negative ideological associations that justify the Israelis atrocities against the Palestinians. S/He used the verb 'endanger ' to show that the Israelis are victims and to picture the Palestinians as agents who perform aggressive acts against them. 
In the translation, the translators transferred the headline with highly emotive overtones. The term ' does not match 'suicide bombers' in the ST. It is highly expressive as it refers to people who have devoted themselves and lives to their cause. By transforming the term 'suicide bombers' into 'منففو العمليات الاستشهادية 'متنشهاديون ','مقاونون', the renderings show maximal mediation by the use of lexical items that are more in circulation in the target context. In doing so, the translators subvert the ideological connotations of the original. By rendering the verb 'endanger' which holds a negative connotation into 'يثيرون/يبثون/يدبون الرعب في قلوب الصهاينة', the translators succeeded in changing the status of Israelis from being victims to being so weak and coward.

\subsection{Rioter Shot Dead by IDF may have been Armed, Says Army}

$$
\begin{aligned}
& \text { - الاحتلال الاسر ائيلي: استشهاد متظاهر فلسطيني على يد قوات الاحتلال كان بحوزته سلاح على حد زعمه } \\
& \text { - لمطيني استشهد على يد قوات الاحتلال الإسر ائيلي كان يحمل سلاح حسب ما يزعم جيش الاحتلال } \\
& \text { - متظاهر استشهد علي يد قوات الاحتلال الصهيوني كان حاملاً للسلاح حسب ما يرويه جيش الاحتلال } \\
& \text { - - فلسطيني استتهد على يد قوات الاحتلال الإسر ائيلي كان يحمل سلاح حسب مانب ما يزعم جيش الاحتلال }
\end{aligned}
$$

The lexis 'rioter' in the ST is highly evaluative as it conveys semantic associations which picture Palestinians as initiators of violence and aggression. The euphemistic linguistic term 'IDF' is also used to portray the Israelis as self-defenders, so whatever actions they take are warranted. The reporter used the neutral verb 'said' with entities that refer to the Israelis.

As for the translators, they turned to neutral reconstruction which empties the message of the ideological connotations embodied in the propositions of the source text when rendering 'rioter' into " "متظاهر , فلسطيني متظاهر فلسطيني

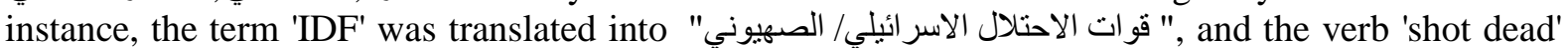
into "استشهـ". The addition of " على حد زعمه/ حسب ما يزعم/ حسب ما يرويه" by all translators injects doubt and suspicion in the ST.

\subsection{Israel Probes Killing of Gaza Amputee after New Footage Surface}

$$
\begin{aligned}
& \text { - - الاحتلال يزعم فتح تحقيق بظروف استشهاد المقعد أبو ثريا }
\end{aligned}
$$

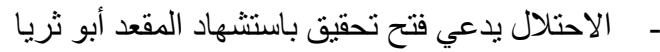

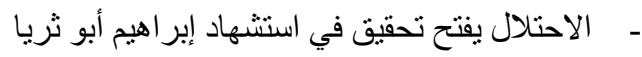

$$
\begin{aligned}
& \text { - الاحتلال يحقق في ظروف استشهاد أبو ثريا }
\end{aligned}
$$

The reporter in the original text reflects a positive image of Israel in that it cares about human rights and how shameful to commit such a horrible act it is! And that it is serious about finding the one who killed the disabled Palestinian. On the other hand, translators recontextualized the ideology of the news headline by first changing "Israel" into "الاحتلال" which holds a negative connotation. Then they added words like 'يزعم/يدعي' to discredit the faithfulness of the ST. However, two translators only rendered 'probe' into its direct equivalent in Arabic 'يزتح تحقيق/يحقق' distancing themselves from any modifications or interventions in the ST.

\subsection{Two Hamas Militants Killed in Retaliation Air Strikes after Rockets Launched from Gaza.}

$$
\begin{aligned}
& \text { - مقاومان من حماس استشهدا في غار ات جوية صهيو نية بعد إطلاق صو اريخ من غزة }
\end{aligned}
$$

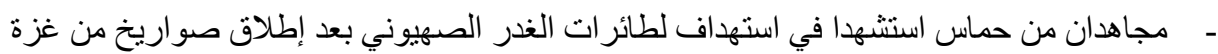

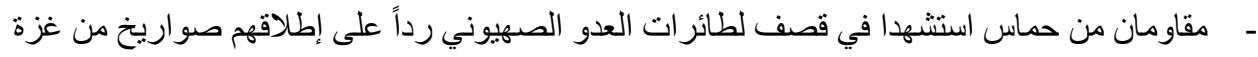

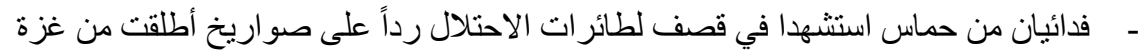

The basic assumption in the source text is that Israelis are the privileged entity, whereas Palestinians are devaluated. Based on this assumption, the Palestinians are pictured as violence initiators when the Israeli reporter used the word 'militants' and the Israelis, on the other hand, are depicted as selfdefending when he used the word 'retaliation'.

Looking at the target texts, it is quite apparent that the lexical items 'مقاومان/مجاهدان/فدائيان ' are not ideologically equivalent to that of 'militants'. The translators also subvert the ideological connotations loaded in the news headline by rendering the word "killed" into "استشهي/2", deleting 'retaliation' and

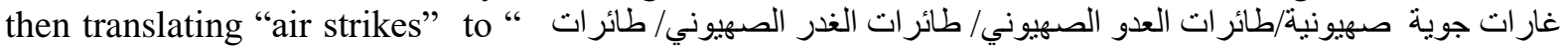
"الاحتلال " to show that they are the source of all evil. 


\subsection{IDF Planes Demolish Hamas Terror Tunnel Under Karem Shalom Border Crossing}

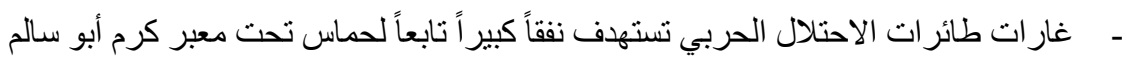

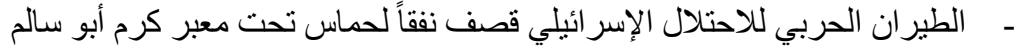

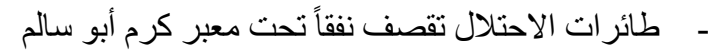

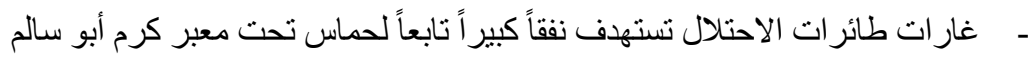

The reporter avoided using the term 'IOF' which refers to Israeli "occupying forces" since it clashes with his/her ideology and the perspective of his country, so s/he used 'IDF' instead. S/He used a highly charged lexis 'Hamas terror' to indicate that Israelis are peace makers while Hamas is a terrorist group that initiates violence so that is why IDF wants to eradicate the tunnel.

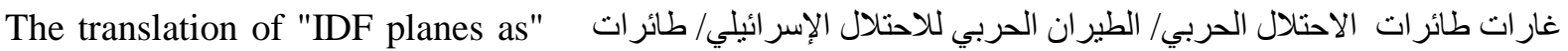
'الاحتلال ideologically mark the IDF as an aggressor and an occupying force. The word 'terror' was deleted, since it is highly evaluative, and by doing so, translators are emptying the message of its negative ideological impulse.

\subsection{Terrorist who Stabbed Israeli Officer Dies of Wounds}

$$
\begin{aligned}
& \text { - شاب استثهد بعد طعنه لضابط صهيوني منأثراً بجر احه }
\end{aligned}
$$

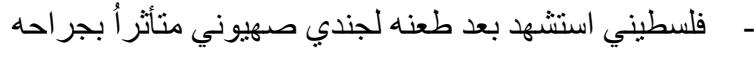

$$
\begin{aligned}
& \text { - }
\end{aligned}
$$

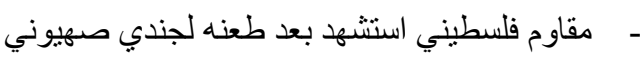

The use of lexical items such as 'terrorist' in the ST reinforces the image of the bad Palestinians who are the real source of violence and aggression. The reporter also used the verb 'dies' which holds a negative connotation.

In the translation however, two translators used neutral translation rendering 'terrorist' into ' شابر فلسطيني'. By this, they removed the extreme negativity embodied in the word 'terrorist'. The other

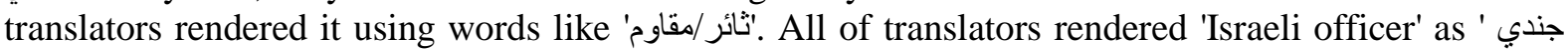
صهيوني/ضابط صهيوني 'استشهدا' they also translated 'dies' as thich holds a positive connotation that he was ready to sacrifice his soul for his country and people. In reproducing these items in the TT, the translators turned to mediation. They freed themselves from the commission and the ST and substituted the original with alternative evaluative nuances in the TT.

\subsection{Ramallah Terrorist Planned to Carry out Suicide Attack}

$$
\begin{aligned}
& \text { - - مقاومون خططو التنفيذ عملية استشهادية في رام الله } \\
& \text { - مجاهدون في رام الله خططوا للقيام بعطلية جهادية }
\end{aligned}
$$

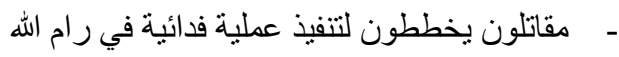

$$
\begin{aligned}
& \text { - - فدائيون يخططون لتنفيذ عملية استشهادية في رام الله }
\end{aligned}
$$

In the source text, the language of the occupier is used to provide the public with negative views about the Palestinians. The choice between 'terrorists' and 'freedom fighters' is not simply one of point of view, but an ideological categorization meant to dehumanize the Palestinians. In this sense, we perceive that the term 'terrorists' has negative nuances like 'self-killers' and this applies for the use of 'suicide attack'.

In rendering 'terrorists', the translators resorted to replacing the ST term with another TT terms that are more acceptable to the target audience such as 'مقاومون/مجاهدون', while the others used ' عملية 'مقاتلون/فدائيون

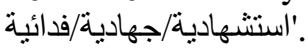

\subsection{Security Guard Seriously Wounded in Jerusalem Terror Attack}

$$
\begin{aligned}
& \text { - - حارس أمن صهيوني أصيب بجر اح خطيرة في عملية فدائية بالقدس }
\end{aligned}
$$

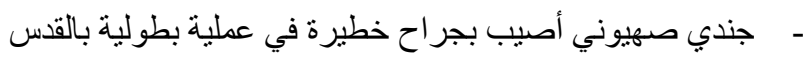

$$
\begin{aligned}
& \text { - - } \\
& \text { - }
\end{aligned}
$$


The Israeli reporter used a dysphemistic term when referring to the Palestinians that is 'terror attack' to portray the Palestinians negatively. The highly sensitive lexical item 'attack' is used when the Israeli casualties are reported.

Fندي صهيوني/جندي 'For the target headline, the journalists/translators have replaced 'security guard' with عملية فدائية/ ' 'إسري/ 'and the highly sensitive lexical item 'attack' is rendered as 'ائيلي/حارس أمن صهيوني 'بطولية/استثهادية 'with some sense of positivity.

\subsection{Terrorist Bodies will not be Returned}

$$
\text { - }
$$

The term ' terrorist' is highly evaluative as it depicts the Palestinian martyrs negatively. While in the translation, the translators have managed to subvert the ideological connotations of that word by rendering it into 'الثهداء' which refers to those who grant their souls for their country.

\subsection{Gazan Man Killed in Clashes with Troops}

$$
\begin{aligned}
& \text { - مو اطن غزي استشهح أثناء مواجهات مع جيش الاحتلال }
\end{aligned}
$$

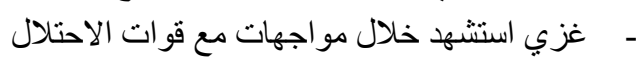

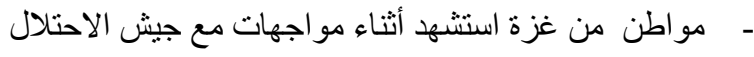

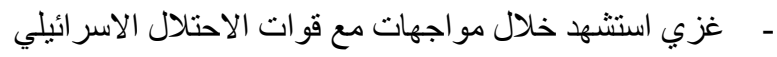

The reporter used a dysphemistic verb which is 'killed' when referring to Palestinians and a euphemistic term which is 'troops' when referring to Israelis. In rendering, the verb 'killed' is

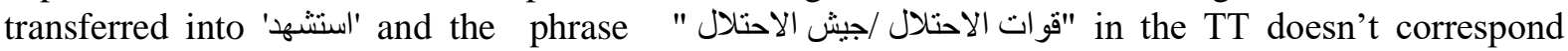
ideologically to that of the ST 'troops', while the term 'occupying forces' in the TT is evaluative.

\subsection{How Security Camera Footage Helped Israel Track Down Killers}

$$
\begin{aligned}
& \text { - كيف ساعدت لقطات كامير ا الاحتلال على تعقب المقاومين }
\end{aligned}
$$

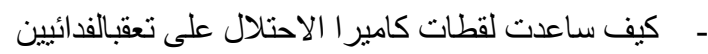

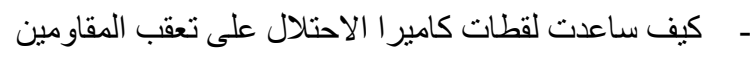

$$
\begin{aligned}
& \text { - كيف ساعدت لقطات كامير ا الاحتلال على تعقب الفدائيين }
\end{aligned}
$$

The use of highly expressive words like 'track down/killers' reflects a total negative image of the Palestinians in that they threaten the security and peace of Israel and they are the ones who perform aggressive acts against the Israelis. However, translators used evaluative lexical items to invert the message by rendering 'Israel' as 'الاحتلال' and 'killers' as 'مقاومون/مجاهدون/فدائيون .

\subsection{PA Minister Claims Israel Violates Muslim Rights at Tomb of Patriarchs}

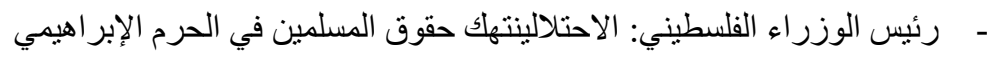

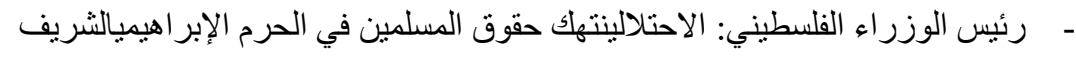

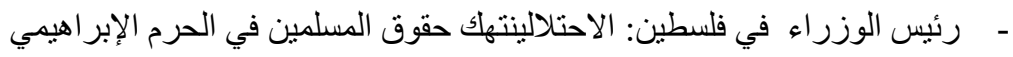

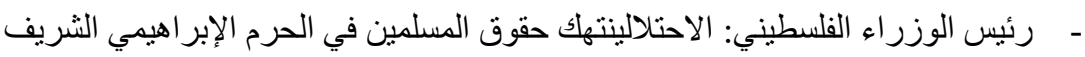

The use of the evaluative verb 'claim' in the ST is used to refer to the Palestinians as to falsify their actions and speeches. The reporter wanted to show that Israel is innocent and has nothing to do with the violations of Muslim rights. On the other hand, the four translators manipulated the situation by rendering 'Israel' as 'الاحتلال/قوات الاحتلال' and deleting the verb 'claim' substituting it by nothing to reflect the total opposite picture of the source text.

\subsection{Israel Air Force Attacks Hamas Targets}

$$
\begin{aligned}
& \text { - طائر ات الاحتلال الصهيوني تقصف أهدافاً للمقاومة }
\end{aligned}
$$

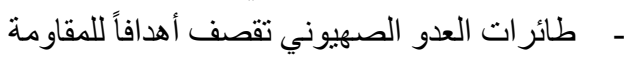




$$
\begin{aligned}
& \text { - طائر ات العدوان الصهيوني تقصف أهدافاً لحماس } \\
& \text { - - }
\end{aligned}
$$

The translators reflected the headline of the ST with similar effect, i.e. they organized the segment of the message following the linear order of the original. However, they made some modifications for some lexes. For instance, the term 'Israel air force' has been turned into ideologically loaded lexes such as 'طائر ات الاحتلال الصهيوني/طائر ات العدو/ طائرات العدوان/ سلاح الجو الصهيوني'. 'Hamas' was translated by

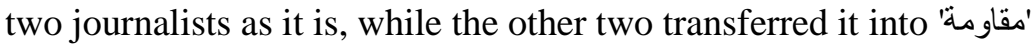

\subsection{Security Forces Arrest, Interrogate 26 Terrorists}

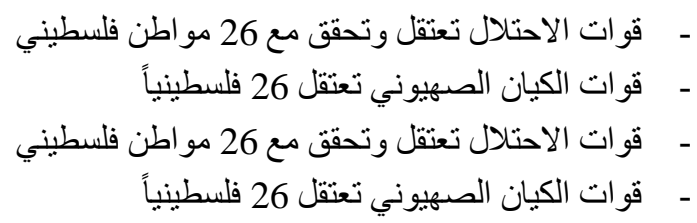

The language choices such as 'security forces/terrorists' represent the Israelis not as occupiers, but rather as people who have the right to defend their presence in the Palestinian territories. Translators intervened in the translation by rendering 'security forces' into 'قو ات الاحتلال/قوات الكيان الصهيوني 'All of them translated 'terrorists' neutrally as 'فلسطينياً/مواطن فلسطيني' to portray Israel as unjust and violent initiator.

\subsection{Death Penalty for Terrorists will Lead to Kidnapping of Jews}

$$
\begin{aligned}
& \text { - - قانون إعدام الفلسطينيين سيسبب موجة اختطاف لليهود }
\end{aligned}
$$

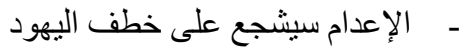

$$
\begin{aligned}
& \text { - - إعدام الفلسطينيين سيسبب موجة اختطاف لليهود } \\
& \text { - - قانونالإعدام سيشجع على خطف اليهود - }
\end{aligned}
$$

The Israeli reporter used the word ' terrorists' to depict the Palestinians as rioters and to reflect negative views about them. However, three translators translated 'terrorists' neutrally as 'الفلسطينيين' and one didn't even mention it.

\section{CONCLUSION}

This research paper examined how political ideology interferes in the process of translating journalistic news headlines. That is implemented through using managing technique in translation in which translators used modification, adjustment, alteration, mediation, and deletion without adhering to the ST. The process of translation is governed by three factors: the readership, the policy of publishing institution, and the ideology of the translator. In this paper, translators address the Palestinian readership, who refuse any translation that portrays a negative depiction of them. So the visibility of the translators has become obvious from the political and ideological affiliations which might conflict with those of the author of the original text. After analyzing the translations of the news headlines, we can conclude that formal equivalence and fidelity cannot be successful options in the translation of sensitive texts since ideologies, purposes, and discourse worlds of both translators and authors are completely divergent hence dynamic equivalence seems to be the most commonly used method in translating sensitive news texts impinged with ideology. Respectively, the truth of the source text is questioned and often subverted in the translation.

\section{RECOMMENDATIONS}

- It is good that journalist translators have a repertoire of lexical terms that consist of euphemistic and dysphemistic items that can help them manage the translation.

- It is essential to determine the purpose of translation, audience, and the translation commission when dealing with highly sensitive texts.

- Also when translating sensitive political discourse, it is recommended to use manipulative and discursive strategies where intervention mostly occurs.

- Dynamic equivalence is the best option when translating expressive and evaluative news texts. 


\section{REFERENCES}

[1] Abdalla, A. (1994). "Aspects of Ideology in Translating Literature": Babel 45(1) pp. 16.

[2] Baker, M. (2011). In Other Words: A Coursebook on Translation. London and New York: Routledge.

[3] Bhabha, H. (1994) The Location of Culture, London and New York: Routledge.

[4] Dickins, J., Hervey, S. and Higgins, I. (2016).Thinking Arabic Translation: A Course in Translation Method: Arabic to English.London and New York: Routledge.

[5] Farghal, M. (1993). "Managing in Translation: A Theoretical Model".Meta 38 (2), pp.257- 267.

[6] Fairclough, N. (1995a) Media Discourse, London: Edward Arnold.

[7] Gee, J. (1990). Social Linguistics and Literature: Ideology in Discourse. London: Falmer Press.

[8] Hatim, B. and Mason, I. (1990). Discourse and the Translator. London: Longman.

[9] Lefevere, A. (1992) Translation, Rewriting and the Manipulation of Literary Fame, London and New York: Routledge.

[10] Martin, J. (2015) What is ideology?, Sociologia, Problems E Praticas, 2 (77), pp.9-31

[11] Munday, J. (2016) Introducing Translation Studies: Theories and applications London: Routledge.

[12] Van D., (1985a). Handbook of Discourse Analysis in Society. New York: Academic Press.

[13] Wolf, M. (2000) 'The third space in postcolonial representation', in S. Simon and P. St-Pierre (eds), pp. $127-45$.

Citation: Dr. Mohammed El Haj Ahmed. "Uncovering Political Ideology in the Translation of News Headlines in Relation to Palestinian-Israeli Conflict" International Journal on Studies in English Language and Literature (IJSELL), vol 7, no. 2, 2019, pp. 15-22. doi: http://dx.doi.org/10.20431/2347 -3134.0702003.

Copyright: () 2019 Authors. This is an open-access article distributed under the terms of the Creative Commons Attribution License, which permits unrestricted use, distribution, and reproduction in any medium, provided the original author and source are credited. 